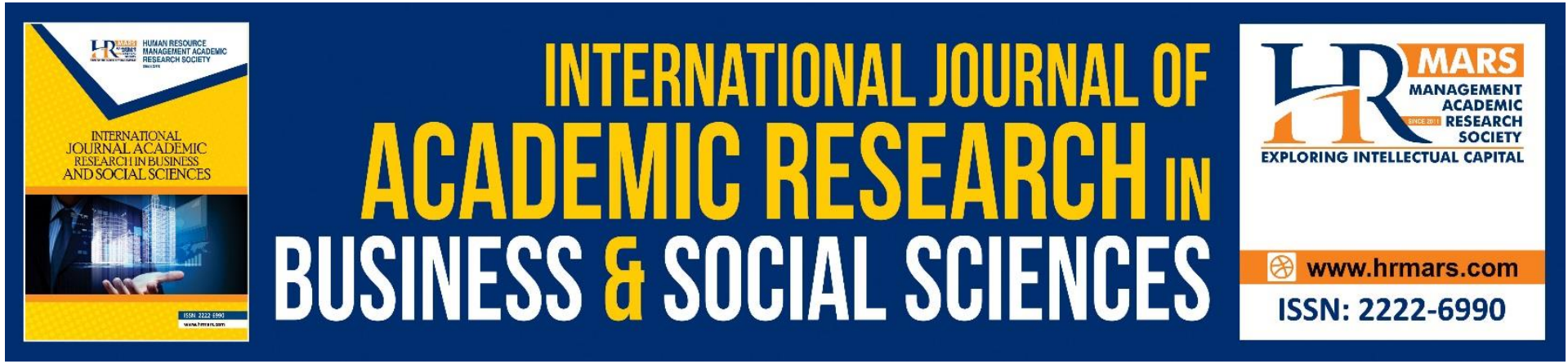

\title{
Supply Chain Risks and Roles of the Strategy of Green Supply Chain Management Practices
}

Norzawani Ibrahim, Razli Che Razak, Mohd Hafeez Al-Amin Abdul Wahab, Adibah Alawiah Osman, Siti Maziah Ab Rahman

To Link this Article: http://dx.doi.org/10.6007/IJARBSS/v11-i7/10322

DOI:10.6007/IJARBSS/v11-i7/10322

Received: 24 May 2021, Revised: 27 June 2021, Accepted: 10 June 2021

Published Online: 26 July 2021

In-Text Citation: (Ibrahim et al., 2021)

To Cite this Article: Ibrahim, N., Razak, R. C., Wahab, M. H. A.-A. A., Osman, A. A., \& Rahman, S. M. A. (2021). Supply Chain Risks and Roles of the Strategy of Green Supply Chain Management Practices. International Journal of Academic Research in Business and Social Sciences, 11(7), 752-771.

Copyright: (c) 2021 The Author(s)

Published by Human Resource Management Academic Research Society (www.hrmars.com)

This article is published under the Creative Commons Attribution (CC BY 4.0) license. Anyone may reproduce, distribute, translate and create derivative works of this article (for both commercial and non-commercial purposes), subject to full attribution to the original publication and authors. The full terms of this license may be seen at: http://creativecommons.org/licences/by/4.0/legalcode

Vol. 11, No. 7, 2021, Pg. 752 - 771

http://hrmars.com/index.php/pages/detail/IJARBSS

JOURNAL HOMEPAGE

Full Terms \& Conditions of access and use can be found at http://hrmars.com/index.php/pages/detail/publication-ethics 


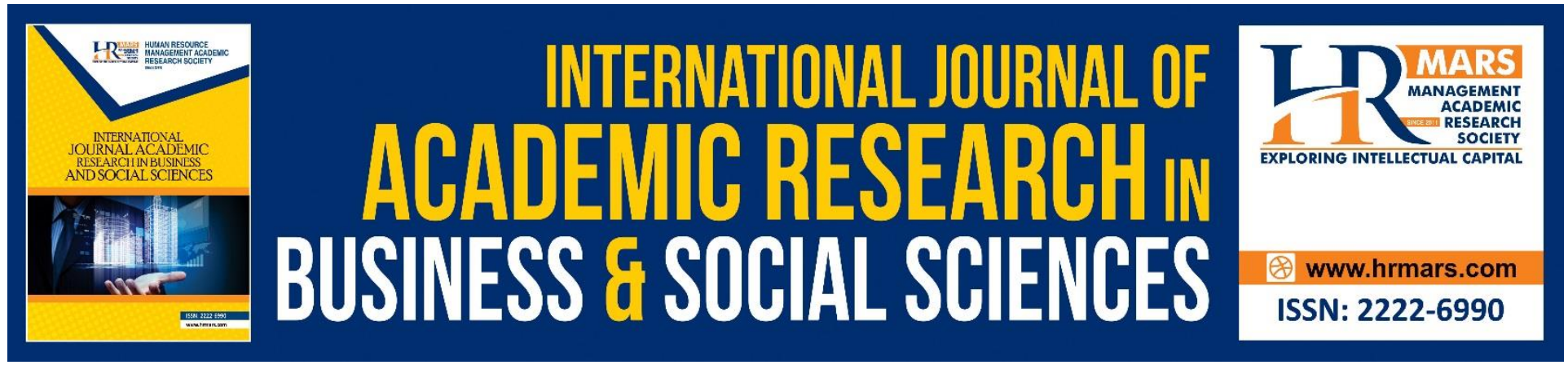

\title{
Supply Chain Risks and Roles of the Strategy of Green Supply Chain Management Practices
}

\author{
Norzawani Ibrahim \\ Faculty of Business and Management, Universiti Teknologi Mara Puncak Alam, Malaysia \\ Email: nzawani@uitm.edu.my \\ Razli Che Razak \\ Faculty of Entrepreneurship and Business, Universiti Malaysia Kelantan \\ Email: razlicr@umk.edu.my
}

Mohd Hafeez Al-Amin Abdul Wahab

Faculty of Business and Management, Universiti Teknologi Mara Cawangan Kelantan

Email: mohdhafeez@uitm.edu.my

\begin{abstract}
Adibah Alawiah Osman
Faculty of Business and Management, Universiti Teknologi Mara Puncak Alam, Malaysia

Email: adibahalawiah@uitm.edu.my

Siti Maziah Ab Rahman

Faculty of Business and Management, Universiti Teknologi Mara Cawangan Kelantan

Email: maziah650@uitm.edu.my
\end{abstract}

\begin{abstract}
Supply chain risk is one of the factors disrupting the performance of an organisation. Furthermore, supply chain risk does not only affect economic performance but will also disrupt environmental performance. The focus of this paper is to explore the relationship between supply chain risks, the role of green supply chain management practices, and organisational performance. In particular, the originality of this paper is it is reviewing the role of green supply chain management practices as a strategy for organisations in order to mitigate supply chain risk and improve organisational performance. Efforts have been made in order to study the connection between supply chain risks, green supply chain management practices, and organisational performance since there is still a lack of studies focus on the roles of the strategy of green supply chain management practices.
\end{abstract}

Keywords: Supply Chain Risks, Green Supply Chain Management Practices, Organisational Performance, Roles of Strategy. 


\section{Introduction}

Academicians and researchers have completed a lot of literature and studies regarding supply chain management and proved that a good supply chain management improves organisational performance (Mutuerandu, 2014; Salazar, 2012; Li et al., 2004). Since supply chain is becoming more complex, the efficiency of supply chain management is one of the factors that contribute to organisational performance. However, organisations have to concern on the influence of the risk in supply chain from every direction (Olson \& Wu, 2010) because there are evidences that supply chain risk has a significant and negative effect on organisational performance (Bavarsad et al., 2014; Hendrick \& Singhal, 2005). Besides that, according to Marchese and Paramasivam (2013), based on the survey by Business Continuity Institute in 2011 , the finding shows that $85 \%$ of the companies from global supply chain involved at least one disruption in the supply chain within 12 months period. In addition, more than 1,000 industrial facilities over the world were affected because of severe floods in Thailand in October 2011 (Business Forward Foundation, 2014). Moreover, the issue of oil spill in Bhopal in 1984 studied by Kleindorfer and Saad (2005) reported that supply chain risk affected economic losses for chemical sectors and directly impacted environmental damages. As a result, the related companies experienced production and sales drop (Business Forward Foundation, 2014), high cost of disruption recovery, heading to fewer revenues, problem in time delivery, increased downtime (Marchese \& Paramasivam, 2013), and reduced environmental reputation (Lintukangas et al., 2014; Freise \& Seuring, 2015; Mangla et al., 2015).

Some literature recently gives attention to both supply chain risk and environmental outcome (Kleindorfer \& Saad, 2005; Rao \& Goldsby, 2009; Freise \& Seuring, 2015). Freise and Seuring (2015) extended their research on supply chain risk, from an economical perspective to a sustainability perspective; however, it is not thoroughly examined. Upon realising the deficiency, it is important for an organisation to identify the supply chain risk and determine the best approach that fits the supply chain activity that meets the environmental protection (Kleindorfer \& Saad, 2005).

A number of studies discussed the advantages of implementing green supply chain management practices in terms of economic performance and environmental performance (Zhu \& Sarkis, 2004; Zhu et al., 2008; Eltayeb \& Zailani, 2007; Kumar \& Chandrakar, 2012; Zhu et al., 2012; Green Jr, et al., 2012; Tachizawa et al., 2015). According to Eltayeb and Zailani (2009), by adopting green supply chain management in the company as a common practice, it will create environmentally-friendly product image, improve processes and systems, as well as improve the technologies. In addition, the business in the organisations also becomes more systematic. Furthermore, the green supply chain management practices is also a new innovative approach and sustainable strategic development to achieve both financial and environmental benefits by reducing environmental risk and environmental impact (Van Hoek, 1999; Hajikhani et al., 2012). Therefore, green supply chain management practices are expected to be a strategy for an organisation in order to overcome the environmental and economic issues in the company, as well as to mitigate risks that can occur in the supply chain (Nikbakhsh, 2009).

The theoretical outlook taken in this research develops from resource-based view (RBV) theory. RBV theory strongly emphasized that tangible and intangible resources are important 
for the firms to achieve the competitive advantage (Wernerfelt, 1984; Barney, 1991). A study by Aziz et al., (2015) highlighted that the firm who is strive to mitigate the supply chain risks is able to survive in the competitive edge. Therefore, the role of green supply chain management practices is observed by this study as a risk mitigation strategy to reduce the effect of supply chain risk and improve the performance of the organization. The originality of the study lies in its review of green supply chain management practices as the role of strategy, which respond to the demand by Aziz et al. (2015) which only focused on agility strategy to reduce the effect of supply chain risk and improve the organizational performance. Therefore, the objective of this research are as follows:

- To explore the relationship between supply chain risks, the role of green supply chain management practices, and organisational performance

- To review the role of green supply chain management practices as a strategy for organisations in order to mitigate supply chain risk and improve organisational performance.

\section{Literature Review \\ Supply Chain Risks}

As we enter the $21^{\text {st }}$ century, companies around the world are facing extreme supply chain challenges. Accordingly, the challenges in supply chain activities involve quality problem, safety challenges, supply shortages issues, environmental compliance, security problem, legal issues, and regulatory, which negatively impact the activity in supply chain network (Christopher, 2005). Apart from the impact on supply chain network, those challenges also negatively impact organisational performance (Wagner \& Bode, 2008; Zhao et al., 2013; Bavarsad et al., 2014; Munyuko, 2015). Qun (2010) refers supply chain risks as potential challenges for supply chain destruction. Besides that, compared to other business areas, supply chain area has a high potential of risk involvement (Christopher, 2005). Also, supply chain could be disrupted due to the inefficient flow of material and blocking information by the supply chain members (Punniyamoorthy et al., 2013). Zhang and Song (2011) expressed the supply chain risk is purely dangerous with the consequences accurately signify the real business in the context of supply chain management. Additionally, based on the study conducted by Wieland and Wallenburg (2012), they highlighted the finding from the survey among supply chain executives, which reported the increasing risk since 2008 and it is still increasing due to several factors. Therefore, supply chain risk is one of the big challenges in supply chain that needs to be solved by practitioners and academicians. There are several definitions of supply chain risk defined by different studies. Based on the study conducted by Manuj and Mentzer (2008), they interpreted the concept of risk from a senior executive in a manufacturing firm, which emphasised:

"Risks are all those things that keep you away from the perfect path and perfect outcomes and (you) got to be able to translate (risks) into dollars somehow".

Besides that, according to Vilko et al (2014) from the study conducted by Mitchell (1995), risk can be defined based on the quantitative formula as follows: "Risk=P (loss) XI (loss), whereby $\mathrm{P}=$ probability and $\mathrm{I}=$ significance".

This definition has been supported by Qazi et al (2015), which pointed out that supply chain risk involves three main components; probability, losses, and significance. They are 
"probability of the occurrence of an event that leads to the realisation of the risk, potential losses in case of realisation of risk, and significance of the consequences of losses". Later on, Mangla et al (2015) also clarified risk as a threat to the organisation that is possible to disturb normal activity of operation. Despite disturbing the operation activity, Zsidisin (2005) and Zsidisin and Ritchie (2008) have proven that supply chain risk is the potential occurrence of an incident or failure to seize opportunities with inbound supply, in which its outcomes result in a financial loss (negative economic performance) for the purchasing firms. Qun (2010) also stressed on supply chain risk as the main reason that made organisation lost their intended targets or objectives. It is parallel with the statement founded by Bavarsad et al (2014) and Tang (2006) whereby supply chain risk is the uncertain event that could affect the supply chain partners in negative vibes and also could impact business performance. Despite that, the presence of risk in supply chain causes the predictors unable to prepare the solution in order to prevent the unexpected events in the organisation (Jiang, 2011). Upon distinguishing the definition of supply chain risk from many academicians, thus this study classified the definitions as Table 2.1.

Table 2.1: Definition of supply chain risk

\begin{tabular}{ll}
\hline \multicolumn{1}{c}{ Author(s) \& Year } & \multicolumn{1}{c}{ Definition } \\
\hline Buddress (2013) & $\begin{array}{l}\text { Supply chain risk refers to the potential incident happened in } \\
\text { supply events that has a significant negative impact on the } \\
\text { purchasing firm. }\end{array}$ \\
Zhao et al. (2013) & $\begin{array}{l}\text { Supply chain risk involves the uncertainty of demand and supply, } \\
\text { unexpected event or disruption and arises turbulent } \\
\text { environment. }\end{array}$
\end{tabular}

Zhang and Song (2011) Supply chain risk is the negative deviation from the expected value of a certain performance measure, resulting in undesirable consequences for the focal firm in the supply chain.

Qun (2010) Supply chain risk is the outcome based on the material flow over the supply chain network, the production and circulation of large enterprise customers have commercial, logistics and the flow of information related to transportation, storage and handling, transport, packaging, distribution processing, distribution, information processing, and so on the course, any one aspect of the problem would lead to the risk of the supply chain, affecting its normal operation.

Manuj and Mentzer Supply chain risk involves two major components, which are (2008) potential losses and possibility of those losses. Potential losses are considered as the risks that are already realised by the practitioners, thus the risks will be analysed. The possibility of those losses identified as the risk is still not realised by the practitioners. The practitioners have an initial expectation that leads to realise the risk.

Bogataj and Bogataj The potential occurrence in supply chain that decreases the (2007) value added at any activity cell in the chain, where the outcome is explained through the quantity and quality of goods in any location and time in a supply chain flow. 


\begin{tabular}{ll}
\hline Goh et al. (2007) & $\begin{array}{l}\text { Internal supply chain risk- supply risk, demand risk, and trade } \\
\text { credit risk. }\end{array}$ \\
& $\begin{array}{l}\text { External supply chain risk- the risk occurs at the interactions } \\
\text { between the supply chain network, and the risk occurs at the } \\
\text { supply chain environment. }\end{array}$ \\
Kleindorfer and Saad & $\begin{array}{l}\text { Supply chain risk comes from the problem of supply and } \\
\text { demand, and also from the unexpected disruption of normal } \\
\text { (2005) }\end{array}$ \\
\hline
\end{tabular}

Basically, supply chain risk refers to the unexpected event that gives negative sense to the performance (Mangla et al., 2015; Qazi et al., 2015; Bavarsad et al., 2014; Vilko et al., 2014; Kleindorfer \& Saad, 2005). However, according to Florian and Costangiora (2013), supply chain risk does not only cause negative outcome, but the result might be positive. This study intends to use the definition produced by Zhang and Song (2011), which clarified supply chain risk as a negative deviation resulting in undesirable outcome to organisational performance.

In the book by Zsidisin and Ritchie (2008) entitled "Supply Chain Risk: A Handbook of Assessment, Management, and Performance", the authors highlighted that supply chain risk encompasses a multi-dimensional construct. Hence, it is important to identify and classify the antecedents of supply chain risk in order to contribute in managerial decisions (Ya-feng \& Qihua, 2009). Due to the multi-dimensional constructs of supply chain risk, basically, supply chain risk has been divided into two categories; internal supply chain risk and external supply chain risk (Buddress, 2014; Gilaninia et al., 2013; Olson \& Wu, 2010). Olson and Wu (2010) identified competitor and market risk, nature risk, and political system risk are included in external supply chain risk, meanwhile internal supply chain risk encompasses available capacity risk, internal operation risk, and information system risk. The study conducted by Jiang (2011) focused on procurement, finance and management, demand, and production as supply chain risks. Qun (2010) highlighted supply chain risk in different views, which are uncertainty between node enterprise, uncertainty in node enterprise, uncertainty of market demand, and uncertainty of external environment. Zhang and Song (2011) categorised supply chain risk as demand risk and supply risk. Corresponding to the classification by Zhang and Song (2011), Zhao et al. (2013) divided supply chain risk into supply delivery risk and demand variability risk. Since the dimensions of supply chain risk vary, as provided by different studies, therefore this study sorts the supply chain risk's dimensions by authors as Table 2.2. 
Table 2.2: Dimensions of supply chain risk

\begin{tabular}{|c|c|}
\hline Author(s) \& Year & Supply Chain Risk's Dimensions \\
\hline Ho et al. (2015) & $\begin{array}{l}\text { Macro risk, demand risk, manufacturing risk, supply risk, and } \\
\text { infrastructural risk. }\end{array}$ \\
\hline Munyuko (2015) & $\begin{array}{l}\text { Environmental risk, technological risk, political risk, market } \\
\text { risk, financial risk, and organisational management risk. }\end{array}$ \\
\hline Freise and Seuring (2015) & Social risk and environmental risk. \\
\hline Avelar-Sosa et al. (2014) & Process risk, demand risk, and suppliers risk \\
\hline Buddress (2013) & $\begin{array}{l}\text { Internal supply chain risk- policies, resources, operational, } \\
\text { and time compression. } \\
\text { External supply chain risk- governmental actions, lack of } \\
\text { infrastructure, supplier problem, logistical problem, price, } \\
\text { terrorism, natural disasters, and accidents. }\end{array}$ \\
\hline $\begin{array}{l}\text { Punniyamoorthy et al. } \\
\text { (2013) }\end{array}$ & $\begin{array}{l}\text { Manufacturing side risk, demand side risk, logistic side risk, } \\
\text { information risk, and environment risk. }\end{array}$ \\
\hline Bandaly (2012) & $\begin{array}{l}\text { Internal operation, external stakeholders, marketplace, and } \\
\text { environment. }\end{array}$ \\
\hline Ghadge et al. (2012) & Organisational risk, network risk, and environmental risk. \\
\hline Christopher et al. (20 & $\begin{array}{l}\text { Supply risk, demand risk, control risk, process risk, and } \\
\text { environmental risk. }\end{array}$ \\
\hline Diabat et al. (2012) & $\begin{array}{l}\text { Macro-level risk, demand management risk, supply } \\
\text { management risk, product/service management risk, and } \\
\text { information management risk. }\end{array}$ \\
\hline Ya-feng and Qi-hua (2009) & $\begin{array}{l}\text { Selection of vendors, mutual trust between partners, } \\
\text { selection of clients, bad record of partners, designing of } \\
\text { cooperation program, fluctuation of market, information } \\
\text { delivery, and inventory level set. }\end{array}$ \\
\hline $\begin{array}{l}\text { Manuj and Mentzer } \\
\text { (2008) }\end{array}$ & Supply risk, operational risk, security risk, and demand risk. \\
\hline Wagner and Bode (2008) & $\begin{array}{l}\text { Demand side risk, supply side risk, regulatory, legal, and } \\
\text { bureaucratic risk, infrastructure risk, and catastrophic risk. }\end{array}$ \\
\hline $\begin{array}{l}\text { Bogataj and Bogataj } \\
\text { (2007) }\end{array}$ & Supply risk, process risk, demand risk, and control risk. \\
\hline Chopra and Sodhi (2004) & $\begin{array}{l}\text { Disruption, system, procurement, delays, receivables, } \\
\text { inventory, intellectual property, forecast, and capacity. }\end{array}$ \\
\hline $\begin{array}{l}\text { Christopher and Peck } \\
\text { (2003) }\end{array}$ & $\begin{array}{l}\text { Process risk, control risk, demand risk, supply risk, and } \\
\text { environmental risk. }\end{array}$ \\
\hline
\end{tabular}

\section{Green supply chain management (GSCM) practices}

Green supply chain management (GSCM) practice is introduced or designed because of the environmental consideration through decision-making at all stages in the supply chain network, starting from organisation's materials management and logistics function, through post-consumer disposal (Handfield et al., 2005; Simpson \& Power, 2005). As stated by Singh (2010), GSCM practice can be defined as an environmentally conscious for suppliers, manufacturers, retailers, and customers (supply chain members) to save the cost, reduce the delivery time, and increase the efficiency of production. In addition, it will also improve the performance of market growth, financial, and fulfil customers' need. The customers' values 
and profits among supply chain partners will achieve the maximum level if the supply chain network is effective (Lockamy III, 2014).

Bowen et al. (2001) and Hajikhani et al. (2012) stated that GSCM practices are cooperative proactive environment, green strategic procurement, and supply chain management approach to develop suitable and correct capabilities for managing green supply chain. Specifically, GSCM can be described as a practice linking environmental conscious in all supply chain's stages including purchasing activity, production, managing material, logistic (inbound and outbound), and reverse logistic (Baresel-Bofinger et al., 2012). Besides that, GSCM practice has been introduced by the business management team to support the high demand of environmentally-friendly product (Field \& Sroufe, 2007), improve environmental performance, and for cost reduction. GSCM practices aim to minimise the negative impact of supply chain on the environment (Gurtu et al., 2015). It has been highlighted by Zhu and Sarkis (2004) that GSCM practices have emerged and have been an important practice in supply chain in order to obtain high profit and market share by reducing environmental risk and increasing the efficiency of ecology. It has also been supported by Kumar and Chandrakar (2012) that GSCM practices are important in order to reduce environmental risk. As such, according to Groznik and Erjavec (2012), the word 'green practice' is related to green economy, whereby it aims to improve three main things: improve social equity, reduce environmental risk, and improve ecological problem.

\section{Roles of strategy of green supply chain management practices}

Several studies accounted the importance of GSCM practices towards organisational performance (Samaranayake \& Layangani, 2015; Tachizawa et al., 2015; Chien, 2014; Laosirihongthong et al., 2013; Green Jr. et al., 2012; Lee et al., 2012; Zhu et al., 2012; Chien \& Shih, 2007; Zhu \& Sarkis, 2004); however, the context of strategic role has not been given much attention in past research. As stated by the Department of Trade and Industry (2002), supply chain risk is a part of supply chain vulnerability. An arising supply chain risk is a serious disturbance for supply chain network. It means that the supply chain risk is able to affect the supply chain network, and indirectly gives problem to the company in order to sustain the network routine among supply chain members. Hence, the risk in the supply chain should be avoided by the company to assure the activities in the entire chain run smoothly. For some industries, managing supply chain risk has become a prerequisite to the company to succeed in the supply chain or even survive in the business world (O'Keeffe, 2005). In addition, supply chain risk does not only affect economic performance, but it is also able to give adverse effect towards environmental performance (Kleindorfer \& Saad, 2005). Manuj and Mentzer (2008) in their study discussed the idea of matching the strategy that fits external environment in order to prevent risk and generate profits. As cited by Zhu et al (2012) from the study conducted by Sarkis (1995), GSCM has become as "an important strategy for manufacturing company in order to improve performance and achieve high competitive advantage". In connection with that, Lin and Sheu (2012); Su et al (2014) highlighted that GSCM practices are currently becoming an important organisational strategy in global business environment. In support of that statement, Rozar (2013) defined GSCM practices as a "strategy to minimise negative impact on the environment through activities within organisation and supply chain". Therefore, it shows that GSCM practices play a significant role to minimise the risk event in the supply chain. 
Yu et al (2008) highlighted GSCM practices as a role to utilise energy resources efficiently and reduce negative impact on the environment in all aspects of supply chain. Mangla et al. (2015) highlighted several companies adopting green practice in supply chain in order to reduce environmental impact or disruption in their business operations. Besides that, Kumar and Chandrakar (2012) also analysed GSCM practices with different views instead of focusing only being environmentally friendly, in which the practices have also been highlighted as a context of the strategy to achieve higher profit. Gaonkar and Viswanadham (2004) suggested to supply chain practitioners to take care of unexpected events by searching for the safety mechanisms or practices. Since 1990's, Beamon (1999) pointed out the transformation of risk management and pollution prevention into life cycle management and industrial ecology as an extension of environmental management. Hervani et al (2005) supported that life cycle assessment contributes to managers as an environmental management in supply chain. Wu et al (2011) identified that life cycle assessment has been used as a GSCM characteristic to overcome the environmental impact in all stages of product life cycle. Having said so, GSCM practice currently emerges to be an important mechanism to reduce environmental risk in supply chain (Kumar \& Chandrakar, 2012).

As Munyuko (2015) suggested for organisations to identify robust risk management strategies to reduce supply chain risk affecting the effectiveness in supply chain, this study aims to improve organisational performance by the implementation of GSCM practices as a strategic role to reduce supply chain risk. Xu (2011) highlighted GSCM as a practice that utilised resources in order to reduce the power usage in supply chain, reduce pollution, as well as reduce emission. Therefore, by optimising the use of the resources in supply chain, the crisis of sources in the supply chain can be reduced. Olson and Wu (2010) stated the importance for organisations to overcome the crisis of sources that can develop risk in supply chain. By doing so, GSCM practices provide the potential to reduce the risk in supply chain, as well as to improve organisational performance. Table 2.3 shows some literature that highlighted GSCM practices as a role of strategy in order to support the contribution of this study. 
Table 2.3: Roles of strategy of green supply chain management practices

\begin{tabular}{|c|c|c|}
\hline $\begin{array}{l}\text { Author(s) \& } \\
\text { Year }\end{array}$ & Descriptions & Journal \\
\hline $\begin{array}{l}\text { Hajikhani et al. } \\
\text { (2012) }\end{array}$ & $\begin{array}{l}\text { GSCM is a kind of sustainable strategic } \\
\text { development for enterprises in today's } \\
\text { competitive workplace, which has emerged as a } \\
\text { new innovative approach to achieve both } \\
\text { financial and environmental benefits } \\
\text { simultaneously, by reducing environmental risk } \\
\text { and impact. }\end{array}$ & $\begin{array}{l}\text { Australian Journal } \\
\text { of Basic and } \\
\text { Applied Sciences }\end{array}$ \\
\hline Xuxu (2011) & $\begin{array}{l}\text { Green supply chain should make energy cost } \\
\text { reduction and internal environment improve as a } \\
\text { way, and reinforce the ecological environment } \\
\text { and economic development to an organic whole, } \\
\text { stress the enterprise of the chain not only for } \\
\text { their own benefit maximising, but also the } \\
\text { concept of sustainable development and low- } \\
\text { carbon economic concepts into the enterprise } \\
\text { supply chain strategic planning, from the } \\
\text { perspective of product life cycle. }\end{array}$ & $\begin{array}{l}\text { Management and } \\
\text { Service Science } \\
\text { (MASS) }\end{array}$ \\
\hline $\begin{array}{l}\text { Chen et al. } \\
\text { (2010) }\end{array}$ & $\begin{array}{l}\text { The GSCM as a strategic and decision-making } \\
\text { perspective improve firm's present } \\
\text { performance. }\end{array}$ & $\begin{array}{l}\text { Industrial } \\
\text { Engineering and } \\
\text { Engineering } \\
\text { Management } \\
\text { (IEEM) }\end{array}$ \\
\hline $\begin{array}{l}\text { Diabat and } \\
\text { Govinden } \\
\text { (2011) }\end{array}$ & $\begin{array}{l}\text { Three important things that can be described as } \\
\text { a green supply chain are environment, strategy, } \\
\text { and logistic. }\end{array}$ & $\begin{array}{l}\text { Resource, } \\
\text { Conservation, and } \\
\text { Recycling }\end{array}$ \\
\hline $\begin{array}{l}\text { Green Jr. et al. } \\
(2012)\end{array}$ & $\begin{array}{l}\text { Economic performance and environmental } \\
\text { performance can be successfully improved if the } \\
\text { organisations successfully implemented the } \\
\text { GSCM practices that can support operational } \\
\text { and organisation. }\end{array}$ & $\begin{array}{l}\text { Supply Chain } \\
\text { Management: An } \\
\text { International } \\
\text { Journal }\end{array}$ \\
\hline $\begin{array}{l}\text { Meera and } \\
\text { Chitramani } \\
(2014)\end{array}$ & $\begin{array}{l}\text { GSCM practices are the revolution for the } \\
\text { organisation to foster win-win strategies in } \\
\text { order to reduce environmental risk, improve } \\
\text { environmental efficiency, and gain profit. }\end{array}$ & $\begin{array}{l}\text { International } \\
\text { Journal of Scientific } \\
\text { and Research } \\
\text { Publications }\end{array}$ \\
\hline
\end{tabular}

\section{Organisational Performance}

Organisational performance is a very common concept that is always discussed in academic literature. This is because the performance of an organisation is the engine for developing nations (Gavrea et al., 2011). Therefore, the definition of organisational performance varies and needs to be identified by the researcher according to the objectives of the study. The definition of organisational performance was identified since 1950's and continuous changes in align with organisational objectives become more complex from day to day. It will be interesting to determine the definition of organisational performance with different contexts. Thus, Gavrea et al (2011) identified different definitions of organisational performance since 
1950's until 2000's. Table 2.4 presents the definition of organisational performance from the era of 1950's until 2000's:

Table 2.4: Stages of organisational performance definition

(Source: Gavrea et al., 2011)

\begin{tabular}{|c|c|c|}
\hline Timeline & Definition & Context \\
\hline 1950 's & $\begin{array}{l}\text { "The extent to which } \\
\text { organisations viewed as a social } \\
\text { system fulfilled their objectives" } \\
\text { (Geogropoulos \& Tannenbaum, } \\
\text { 1957). }\end{array}$ & $\begin{array}{l}\text { Throughout this time, the } \\
\text { performance was evaluated based } \\
\text { on work, people, and organisational } \\
\text { structure. }\end{array}$ \\
\hline 1960's-1970's & $\begin{array}{l}\text { “Organisation's ability to exploit } \\
\text { its environment for accessing and } \\
\text { using limited resources" } \\
\text { (Yuchtman \& Seashore, 1967). }\end{array}$ & $\begin{array}{l}\text { During this time, the performance } \\
\text { was evaluated based on the ability } \\
\text { of the organisation to utilise the } \\
\text { limited resources and exploit the } \\
\text { organisation's environment. }\end{array}$ \\
\hline 1980's-1990's & $\begin{array}{l}\text { "Organisation that achieves its } \\
\text { performance objectives based on } \\
\text { the constraints imposed by the } \\
\text { limited resources" (Lusthaus \& } \\
\text { Andrien, 1998). }\end{array}$ & $\begin{array}{l}\text { At this time, the aim of the } \\
\text { organisation is to be success in } \\
\text { utilising minimum resources. Profit } \\
\text { has been highlighted as an indicator. }\end{array}$ \\
\hline 2000's & $\begin{array}{l}\text { "Performance is a set of financial } \\
\text { and non-financial indicators } \\
\text { which offer information on the } \\
\text { degree of achievement of } \\
\text { objectives and results" (Lebans \& } \\
\text { Euske, 2002). }\end{array}$ & $\begin{array}{l}\text { In the era of } 2000 \text { 's, the } \\
\text { performance of an organisation is } \\
\text { defined based on two elements, } \\
\text { which are financial and non- } \\
\text { financial. Besides that, the definition } \\
\text { of organisational performance has } \\
\text { evolved and includes many } \\
\text { indicators. }\end{array}$ \\
\hline
\end{tabular}

The growth of the definitions of organisational performance shows that consulting firms and practitioners are continuously focusing on performance improvement. As clarified by Aziz et al (2017); Gavrea et al (2011), the performance measurement currently focuses on both financial and non-financial indicators since the organisation's objectives have become more complex. Both financial and non-financial indicators are widely discussed for continuous performance improvement. However, there have been some debates to clarify either financial or non-financial indicator is the most appropriate to determine organisational performance (Wang et al., 2015). Kaplan and Norton (1996) disagreed that multiple measurements (financial and non-financial) makes the researchers and the practitioners confused to measure organisational performance. Kaplan and Norton (1996) stated that both financial and non-financial performance as the best indicators to measure organisational performance because the measurement of financial performance will contribute to long-run objectives of the business life, whereas non-financial performance supports the success of financial performance (Wang et al., 2015). Lee et al (2004) also used both financial and nonfinancial performance to measure organisational performance, whereby it combined marketoriented goal and financial goal as the indicators of organisational performance. De Waal (2007); Epstein (2004) supported that the achievement of high organisational performance is 
determined by the combination of strong financial performance and strong non-financial performance (customers and employee's satisfaction, high-level individual initiative, productivity and innovation, reward system, and strong leadership).

In operation management, when supply chain management practice is effectively managed by practitioners to achieve competitive advantage, they are required to have performance measurements as a reference in order to monitor the level of their organisation. This study has already discussed in general regarding financial and non-financial performance as the indicators for organisational performance. To further the context of the area of this study, this study adapted the performance measurement that has been applied in GSCM literature. As stated by Laosirihongthong et al (2013), their study focused on cost reduction and profitability to measure economic performance, reduction of emission, reduction of hazards, and usage of material to measure environmental performance. Since supply chain risk also affects environmental performance, rather than only affecting economic performance of the organisation, therefore, economic performance (Chien, 2014; Laosirihingthong et al., 2013; Zhu et al., 2012; Zhu \& Sarkis, 2004) and environmental performance (Tachizawa et al., 2015; Chien, 2014; Laosirihongthong et al., 2013; Green Jr. et al, 2012; Zhu et al., 2012; Zhu \& Sarkis, 2004) are included as the indicators for organisational performance.

\section{Economic Performance}

Venkatraman and Ramanujam (1986) stated that financial performance is a part of economic achievements of firms. Therefore, the indicators in financial performance are equal to the indicators used in economic performance. According to Zhu and Sarkis (2004), economic performance is an important indicator for the organisation which implements environmental practice. This statement is supported by the study conducted by Rennings et al (2006) whereby the study focused on technical environmental innovations as an environmental practice towards economic performance as an outcome. In 1984, the study conducted by Dess and Robinson Jr. highlighted that return on assets (ROA) and sales growth are the most popular measurements for economic performance. The economic performance indicators have been further discussed in the study conducted by Balabanis et al (1998), whereby they divided economic performance into two major variables, which are accounting based (return on capital employed, return on equity, gross profit to sales' ratio) and capital market based (excess market valuation, firm's systematic risk). Rennings et al (2006) stated the 'number of employees', 'organisation's turnover', and 'number of export' as the economic performance indicators. Besides that, Sellers-Rubio (2010) indicated seven elements to measure economic performance, which are net income, earnings before interest and tax, assets, total debt, equity, investment, and number of employees.

\section{Environmental Performance}

As stated before, when supply chain practice is effectively managed by an organisation, it needs measurement as a benchmark for the organisation to identify their level in the business industry. However, not all the practices can be measured using economic performance. Some of the management practices such as green practice or other related factors are appropriate to use environmental performance for the measurement. Even though economic performance is highly influential among the organisation to achieve competitive advantage, Khor (2013) stated that environmental performance also influences firm regarding superior competition among organisations. Environmental performance is concentrating on 
decreasing the level of emission and environmental pollutants (Green Jr. et al, 2012). Positive environmental performance can be seen based on the reduction of emission, reduction of waste, reduction of pollution, and reduction of hazards in operation and production (Abd. Rahman et al., 2014). Chien and Shih (2007) used the definition of environmental performance from Sharma and Vredenburg (1998), which is the environmental impact that comes from the business or corporation's activity involving natural environment. Chien and Shih (2007) also highlighted on OPI (operative performance indicators) and MPI (management performance indicators) as the indicators for environmental performance. OPI primarily involves the materials used, energy management by the firm, waste, emission, and pollution from the production process, whereas MPI is more on what the organisation or administration has done in order to improve environmental performance. It encompasses the way an organisation is measured, contributed, and efforts for environmental performance (Chien \& Shih, 2007). Sometimes, environmental regulation can also be a benchmark for the industry to distinguish the level that has already been achieved by the firm. According to Diabat and Govindan (2011) as cited from Reinhrdt (1998), the quality of environment can be validated based on governmental regulation. Therefore, the corporation with suppliers is able to fulfil the environmental regulation indicated by the government (Chien $\&$ Shih, 2007).

Al Khidir and Zailani (2009) observed two major environmental issues in Malaysia due to industrial activity, which are atmospheric pollution and waste (solid and hazardous). The reduction of pollution and waste can be the environmental measurement for the firm to identify their level in terms of environmental performance. The greater reduction of pollution and waste in industry activity, the higher level of environmental performance achieved by the organisation. Different to the study conducted by Tachizawa et al. (2015), environmental performance is measured depending on the attitude of supplier performance towards environmental protection. They observed two approaches; first, how the suppliers monitor the environmental issue, and second is the suppliers' collaboration. Supplier monitoring involves supplier's environmental records, questionnaires, and audit by either the buyer or independent third party, whereas the supplier's collaboration is related to training, new design innovation, and education sharing. These two approaches also help the organisation to improve supplier performance regarding environmental consideration (Tachizawa et al., 2015).

Based on the resource-based view theory introduced by Wernerfelt (1984) and Barney (1991) and the comprehensively review the literature above, this study construct a proposed research framework as Figure 2.1.

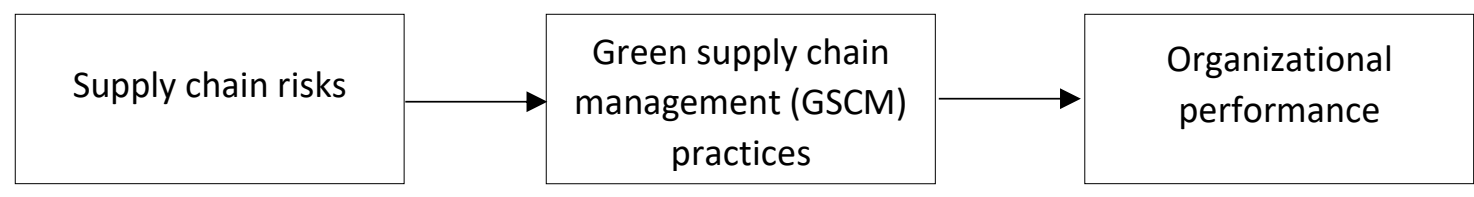

Figure 2.1 Proposed research framework

\section{Conclusion}

Derived from the RBV theory and reviewed the literature regarding supply chain risks, GSCM practices, and organisational performance, it shows the connection between each other. The existence of risks in supply chain will disturb all the supply chain activities, and directly affect 
the performance of the organisation. To remain competitive, the organisation should implement an appropriate strategy in order to overcome supply chain risks and improve organisational performance. By doing so, from the previous study, GSCM practices have been reviewed as a role of strategy to improve the economic and environmental performance of the organisation because of the effect from supply chain risks. Future research is required for more extensive literature regarding the dimensions of supply chain risks and GSCM practices. Besides that, future research is also required to investigate the research framework to highlight the relationship between supply chain risks, GSCM practices, and organisational performance.

\section{Reference}

Al Khidir, T., \& Zailani, S. (2009). Going green in supply chain towards environmental sustainability. Global Journal of Environmental Research, 3(3), 246-251.

Aziz, F., Mahadi, N., Zakaria, W. N. W., \& Mahadi, N. (2017). The impact of Open Innovation and Supply Chain Management towards firm performance. International Journal of Academic Research in Business and Social Sciences, 7(11), 338-344.

Aziz, A. K. A., Rahman, A. A., Kamarulzaman, N. H., \& Sambasivan, M. (2015). The impact of supply chain risk on agility practices: a theoretical review and a critique. Asian Journal of Business and Management (ISSN: 2321-2802), 3(01).

Avelar-Sosa, L., García-Alcaraz, J. L., \& Castrellón-Torres, J. P. (2014). The Effects of Some Risk Factors in the Supply Chains Performance: A Case of Study. Journal of applied research and technology, 12(5), 958-968.

Balabanis, G., Phillips, H. C., \& Lyall, J. (1998). Corporate social responsibility and economic performance in the top British companies: are they linked?. European Business Review, 98(1), 25-44.

Bandaly, D. (2012). Integrated Operational and Financial Approaches in Supply Chain Risk Management. Doctoral dissertation. Quebec, Canada: Concordia University Montreal.

Baresel-Bofinger, A. C., Ketikidis, P. H., Koh, S. L., \& Cullen, J. (2012). Green innovation in supply chain management-The case of Greek manufacturing. 1-28.

Barney, J. (1991). Firm resources and sustained competitive advantage. Journal of Management, 17(1), 99-120.

Bavarsad, B., Boshagh, M., \& Kayedian, A. (2014). A study on supply chain risks factors and their impact on organizational performance. International Journal of Operations and Logistics Management, 3(3), 192-211.

Beamon, M. B. (1999). Designing the green supply chain. Logistics Information Management, 12(4), 332-342.

Bogataj, D., \& Bogataj, M. (2007). Measuring the supply chain risk and vulnerability in frequency space. International Journal of Production Economics, 108(1), 291-301.

Bowen, F., Cousins, P., Lamming, R., \& Faruk, A. (2006). Horses for courses: explaining the gap between the theory and practice of green supply. In Greening the supply chain 151172. Springer London.

Buddress, L. (2013). Managing Supply Chain Sustainability and Risk: Keys to Success. Strategic Management, 18(2), 3-16.

Business Forward Foundation. (2014). Severe weather and manufacturing in America: Comparing the cost of droughts, storms and extreme temperatures with the cost of new EPA standards. Retrieved from http://www.businessfwd.org/Severe Weather And Manufacturing In America. 
Chen, C. C., Tseng, M. L., Lin, Y. H., \& Lin, Z. S. (2010). Implementation of green supply chain management in uncertainty. In Industrial Engineering and Engineering Management (IEEM), 2010 IEEE International Conference, 260-264.

Chien, M. K. (2014). Influences of Green Supply Chain Management Practices on Organizational Sustainable Performance. International Journal of Environmental Monitoring and Protection, 1(1), 12.

Chien, M. K., \& Shih, L. H. (2007). An empirical study of the implementation of green supply chain management practices in the electrical and electronic industry and their relation to organizational performances. International Journal of Environmental Science and Technology: (IJEST), 4(3), 383.

Chopra, S., \& Sodhi, M. S. (2004). Managing risk to avoid supply-chain breakdown. MIT Sloan management review, 46(1), 53.

Christopher, M., and Peck, H. (2003). Building the resilient chain. The International Journal of Logistic Management, 15(2).

Christopher, M. (2005). Managing risk in the supply chain. Supply Chain Practice. Logistics \& Supply Chain Management, 7(2), 4-21.

Christopher, M., Mena, C., Khan, O., \& Yurt, O. (2011). Approaches to managing global sourcing risk. Supply Chain Management: An International Journal, 16(2), 67-81.

De Waal, A. A. (2007). The characteristics of a high performance organization. Business Strategy Series, 8(3), 179-185.

Department of Trade and Industry. (2002). Department of Trade and Industry consolidated resource accounts 2001-2002. Retrieved from https://www.gov.uk/governmentuploads/system/uploads/attachment/data/file/235 495/0280.pdf.

Dess, G. G., \& Robinson, R. B. (1984). Measuring organizational performance in the absence of objective measures: the case of the privately-held firm and conglomerate business unit. Strategic management journal, 5(3), 265-273.

Diabat, A., Govindan, K., \& Panicker, V. V. (2012). Supply chain risk management and its mitigation in a food industry. International Journal of Production Research, 50(11), 3039-3050.

Diabat, A., \& Govindan, K. (2011). An analysis of the drivers affecting the implementations of green supply chain management. Resources, Conservation and Recycling, 55(6), 659667.

Eltayeb, T., \& Zailani, S. H. M. (2007). The implementation of green supply chain management practices: a conceptual framework. Penang: Universiti Sains Malaysia.

Eltayeb, T. K., \& Zailani, S. (2009). Going green through green supply chain initiatives towards environmental sustainability. Operations and Supply Chain Management, 2(2), 93110.

Epstein, M. J. (2004). The drivers and measures of success in high performance organizations. Performance measurement and management control: superior organizational performance. Studies in managerial and financial accounting, 14.

Field, J. M., \& Sroufe, R. P. (2007). The use of recycled materials in manufacturing: implications for supply chain management and operations strategy. International Journal of Production Research, 45(18-19), 4439-4463.

Florian, G. L., \& Constangioara, A. (2014). The Impact of Risks in Supply Chain on Organizational Performances: Evidence from Romania. Economia. Seria Management, 17(2), 265-275. 
Freise, M., \& Seuring, S. (2015). Social and environmental risk management in supply chains: a survey in the clothing industry. Logistics Research, 8(1), 1-12.

Gaonkar, R., \& Viswanadham, N. (2004). A conceptual and analytical framework for the management of risk in supply chains. In Robotics and Automation, 2004. Proceedings. ICRA'04. 2004 IEEE International Conference, 3, 2699-2704. IEEE.

Gavrea, C., Ilies, L., \& Stegerean, R. (2011). Determinants of organizational performance: the case of Romania. Management \& Marketing, 6(2), 285.

Georgopoulos, B. S., \& Tannenbaum, A. S. (1957). A study of organizational effectiveness. American Sociological Review, 22(5), 534-540.

Ghadge, A., Dani, S., \& Kalawsky, R. (2012). Supply chain risk management: present and future scope. The International Journal of Logistics Management, 23(3), 313-339.

Gilaninia, S., Ganjinia, H., \& Mahdikhanmahaleh, B. A. (2013). Difference between Internal and External Supply Chain Risks on its Performance. Nigerian Chapter of Arabian Journal of Business and Management Review, 1(3), 62-68.

Goh, M., Lim, J. Y., \& Meng, F. (2007). A stochastic model for risk management in global supply chain networks. European Journal of Operational Research, 182(1), 164-173.

Green, Jr. K. W., Whitten, D., \& Inman, R. A. (2008). The impact of logistics performance on organizational performance in a supply chain context. Supply Chain Management: An International Journal, 13(4), 317-327.

Groznik, A., \& Erjavec, J. (2012). Environmental Impact of Supply Chains. Pathways to Supply Chain Excellence, 115-124.

Gurtu, A., Searcy, C., \& Jaber, M. Y. (2015). An analysis of keywords used in the literature on green supply chain management. Management Research Review, 38(2), 166-194.

Hajikhani, M., Abdul Wahat, W. B. N., \& Idris, K. B. (2012). Considering on green supply chain management drivers, as a strategic organizational development approach, Malaysian perspective. Australian Journal of Basic and Applied Sciences, 6(8), 246-265.

Handfield, R., Sroufe, R., \& Walton, S. (2005). Integrating environmental management and supply chain strategies. Business strategy and the environment, 14(1), 1-19.

Hendricks, K. B., \& Singhal, V. R. (2005). An empirical analysis of the effect of supply chain disruptions on long-run stock price performance and equity risk of the firm. Production and Operations management, 14(1), 35-52.

Hervani, A. A., Helms, M. M., \& Sarkis, J. (2005). Performance measurement for green supply chain management. Benchmarking: An International Journal, 12(4), pp. 330-353.

Ho, W., Zheng, T., Yildiz, H., \& Talluri, S. (2015). Supply chain risk management: a literature review. International Journal of Production Research, 53(16), 5031-5069.

Jiang, F. (2011). The Assessment of Supply Chain Risk Based on Scenario Analysis. In Information Technology, Computer Engineering and Management Sciences (ICM), 2011 International Conference, 4, 186-190. IEEE.

Kaplan, R. S., \& Norton, D. P. (1996). Linking the balanced scorecard to strategy. California management review, 39(1), 53-79.

Khor, K. S. (2013). Relationship between green product design, reverse logistics product disposition and business performance among electrical and electronic manufacturing firms. Kedah: Universiti Utara Malaysia.

Kleindorfer, P. R., \& Saad, G. H. (2005). Managing disruption risks in supply chains. Production and operations management, 14(1), 53-68. 
Kumar, R., \& Chandrakar, R. (2012). Overview of green supply chain management: operation and environmental impact at different stages of the supply chain. International Journal of Engineering and Advanced Technology, 1(3), 1-6.

Laosirihongthong, T., Adebanjo, D., \& Tan, K. C. (2013). Green supply chain management practices and performance. Industrial Management and Data Systems, 113(8), 10881109.

Lebans, M., Euske, K. (2006). A conceptual and operational delineation of performance. Business Performance Measurement, Cambridge University Press.

Lee, S. M., Kim, S. T., \& Choi, D. (2012). Green supply chain management and organizational performance. Industrial Management \& Data Systems, 112, 8.

Lee, J., \& McKibbin, W. J. (2004). Estimating the global economic costs of SARS. Retirieved from http://www.ncbi.nlm.nih.gov/books/NBK92473/.

Li, S., Nathan, B. R., Nathan, T. S., \& Rao, S. S. (2004). The impact of supplychain management practices on competitive advantage and organizational performance. The international Journal of Management Science, 34, 107-124.

Lin, R. J., \& Sheu, C. (2012). Why do firms adopt/implement green practices?-an institutional theory perspective. Procedia-Social and Behavioral Sciences, 57, 533-540.

Lintukangas, K., Kähkönen, A. K., \& Tuppura, A. (2014). Green supply management-the influence of strategic supply and end-customer orientation. International Journal of Procurement Management 24, 7(5), 582-595.

Lockamy III, A. (2014). Industrial Management \& Data Systems Assessing disaster risks in supply chains. Industrial Management \& Data Systems, 114(5), 755-777.

Lusthaus, C., \& Adrien, M. H. (1998). Organizational assessment: A review of experience. Universalia Occasional Paper, 31.

Mangla, S. K., Kumar, P., \& Barua, M. K. (2015). Risk analysis in green supply chain using fuzzy AHP approach: a case study. Resources, Conservation and Recycling, 104, 375-390.

Manuj, I., \& Mentzer, J. T. (2008). Global supply chain risk management strategies. International Journal of Physical Distribution \& Logistics Management, 38(3), 192-223.

Marchese, K., \& Paramasivam, S. (2013). The Ripple Effect, How Manufacturing and Retail Executives View the Growing Challenge Of Supply Chain Risk. Deloitte Publication, New York.

Meera, B. L., \& Chitramani, P. (2014). Environmental sustainability through green supply chain management practices among Indian manufacturing firms with special reference to Tamilnadu. International Journal of Scientific and Research Publications, 4(3), 22503153.

Mutuerandu, M. K. (2014). Impact of suppply chain management pracitces on organizational performance: A case study of Haco Industries Limited (Kenya). Journal of business and management, 16(4), 62-64.

Munyuko, C. W. (2015). Effects of supply chain risk management on organization performance: Case of Andy Forwarders Services Limited. International Journal of Academic Research in Business and Social Sciences, 5(3), 380-403.

Nikbakhsh, E. (2009). Green supply chain management. Supply Chain and Logistics in National, International and Governmental Environment Contributions to Management Science, 195-220.

Olson, D. L., \& Wu, D. D. (2010). A review of enterprise risk management in supply chain. Kybernetes, 39(5), 694-706. 
O'Keeffe, P. (2005). Understanding supply chain risk areas, solutions and plans: a five-part series. The supply chain risk management series. Retrieved from http://www.protiviti.co.uk/.

Punniyamoorthy, M., Thamaraiselvan, N., \& Manikandan, L. (2013). Assessment of supply chain risk: scale development and validation. Benchmarking: An International Journal, 20(1), 79-105.

Qazi, A., Quigley, J., Dickson, A., Gaudenzi, B., \& Ekici, S. O. (2015). Evaluation of control strategies for managing supply chain risks using Bayesian Belief Networks. In Industrial Engineering and Systems Management (IESM), 2015 International Conference, 11461154. IEEE.

Qun, W. (2010). Supply Chain Risk Assessment and Prevention. In 2010 2nd International Conference on E-business and Information System Security. IEEE.

Rao, S., \& Goldsby, T. J. (2009). Supply chain risks: a review and typology. The International Journal of Logistics Management, 20(1), 97-123.

Rennings, K., Ziegler, A., Ankele, K., \& Hoffmann, E. (2006). The influence of different characteristics of the EU environmental management and auditing scheme on technical environmental innovations and economic performance. Ecological Economics, 57(1), 45-59.

Rozar, M. N., Mahmood, W., Hasrulnizzam, W., Ibrahim, A., \& Razik, M. A. (2015). A study of success factors in green supply chain management in manufacturing industries in Malaysia. Journal of Economics, Business and Management, 3(2), 287-291.

Salazar, R. M. (2012). The effect of supply chain management processes on competitive advantage and organizational performance. Ohio: Air Force Institute of Technology.

Samaranayake, T. N., \& Layangani, L. D. C. S. (2015). Impact of greening the supply chain on economic performance and competitiveness of manufacturing companies in Sri Lanka. In Moratuwa Engineering Research Conference (MERCon), 222-227. IEEE.

Sarkis, J. (1995). Manufacturing strategy and environmental consciousness. Technovation, 15(2), 79-97.

Sellers-Rubio, R. (2010). Evaluating the economic performance of Spanish wineries. International Journal of Wine Business Research, 22(1), 73-84.

Sharma, S., \& Vredenburg, H. (1998). Proactive corporate environmental strategy and the development of competitively valuable organizational capabilities. Strategic management journal, 19(8), 729-753.

Simpson, D. E., \& Power, D. J. (2005). Use the supply relationship to develop lean and green suppliers. Supply Chain Management: An International Journal, 10(1), 60-8.

Singh, S. (2010). Study of green supply chain management practices in the Indian Manufacturing Industries. Punjab: Ambedkar National Institute of Technology.

Su, C. S., Shih, C. T., \& Hsu, S. C. (2014). Measuring the risk degree of the Green Supply Chain Management System based fuzzy preference relations. In Applied Mechanics and Materials, 488, 1322-1325. IEEE.

Tachizawa, E. M., Gimenez, C., \& Sierra, V. (2015). Green supply chain management approaches: drivers and performance implications. International Journal of Operations \& Production Management, 35(11), 1546-1566.

Tang, C. S. (2006). Perspectives in supply chain risk management. International Journal of Production Economics, 103(2), 451-488.

Van Hoek, R. I. (1999). From reversed logistics to green supply chains. Supply Chain Management:An International Journal, 4(3), 129-135. 
Venkatraman, N., \& Ramanujam, V. (1986). Measurement of business performance in strategy research: a comparison of approaches. Academy of Management Review,11(4), 801-814.

Vilko, J., Rumpu, A., \& Koivuniemi, J. (2011). Risk management in supply chains: Information exchange, systemic motives and cognitive barriers. In Technology Management in the Energy Smart World (PICMET), 2011 Proceedings of PICMET'11, 1-9. IEEE.

Wagner, S. M., \& Bode, C. (2008). An empirical examination of supply chain performance along several dimensions of risk. Journal of Business Logistics, 29(1), 307-325.

Wang, Y., Bhanugopan, R., \& Lockhart, P. (2015). Examining the quantitative determinants of organizational performance: evidence from China. Measuring Business Excellence, 19(2), 23-41.

Wernerfelt, B. (1984). A resource-based view of the firm. Strategic management journal, 5(2), 171-180.

Wieland, A., \& Wallenburg, M. C. (2012). Dealing with supply chain risks: Linking risk management practices and strategies to performance. International Journal of Physical Distribution \& Logistics Management, 42(10), 887-905.

Wu, K. J., Tseng, M. L., \& Vy, T. (2011). Evaluation the drivers of green supply chain management practices in uncertainty. Procedia-Social and Behavioral Sciences, 25, 384-397.

Xu, X. (2011). Green Supply Chain Management Based on Low-Carbon Economy. In Management and Service Science (MASS), 2011 International Conference on (pp. 1-4). IEEE.

Ya-feng, L., \& Qi-hua, X. (2009). A method of identifying supply chain risk factors. In Software Engineering, 2009. WCSE'09. WRI World Congress, 4, 369-373. IEEE.

Yu, W., Chavez, R., Feng, M., \& Wiengarten, F. (2014). Integrated green supply chain management and operational performance. Supply Chain Management: An International Journal, 19(5/6), 683-696.

Yutchman, E., Seashore, S. (1967), A system resource approach to organisational effectiveness. American Sociological Review, 32, 891-903.

Zhang, Y., \& Song, H. (2011). Impact of policy environment on supply chain risk and its consequences: An empirical examination. In Computer Science and Service System (CSSS), 2011 International Conference, 2270-2273. IEEE.

Zhao, L., Huo, B., Sun, L., \& Zhao, X. (2013). The impact of supply chain risk on supply chain integration and company performance: a global investigation. Supply Chain Management: An International Journal,18(2), 115-131.

Zhu, Q., \& Sarkis, J. (2004). Relationships between operational practices and performance among early adopters of green supply chain management practices in Chinese manufacturing enterprises. Journal of operations management, 22(3), 265-289.

Zhu, Q., Sarkis, J., Cordeiro, J. J., \& Lai, K. H. (2008). Firm-level correlates of emergent green supply chain management practices in the Chinese context. Omega, 36(4), 577-591.

Zhu, Q., Sarkis, J., \& Lai, K. H. (2012). Examining the effects of green supply chain management practices and their mediations on performance improvements. International journal of production research, 50(5), 1377-1394.

Zsidisin, G. A. (2005). Managing commodity spend in turbulent times. CAPS Center for Strategic Supply Research. 
Zsidisin, G. A., \& Ritchie, B. (2008). Supply Chain Risk: A Handbook of Assessment, Management, and Performance. International series in operations research \& management science, ISOR 124, New York. 